\title{
Roles and action mechanisms of herbs added to the emulsion on its lipid oxidation
}

\author{
Eunok Choe $^{1}$ (D)
}

Received: 25 March 2020/Revised: 1 June 2020/ Accepted: 13 July 2020/Published online: 25 July 2020

(C) The Author(s) 2020, corrected publication 2020

\begin{abstract}
Quality of food emulsions is mainly determined by their physicochemical stability such as lipid oxidation, and herbs as antioxidative food materials are added to improve their quality and shelf-life. Despite the extensive researches, the chemistry and implications of herb addition in the lipid oxidation of emulsions are still confusing. This review intended to provide the information on the roles and action mechanisms of herbs in the lipid oxidation of food emulsions, with focuses on polyphenols. Polyphenols act as antioxidants mainly via reactive oxygen species scavenging and metal chelating; however, their oxidation products and reducing capacity to more reactive metal ions increase the lipid oxidation. Factors such as structure, concentration, and distribution determine their anti- or prooxidant role. Interactions, synergism and antagonism, among polyphenol compounds and the effects of tocopherols derived from oil on the antioxidant activity of herbs were also described with the involving action mechanisms.
\end{abstract}

Keywords Herb · Polyphenol - Lipid oxidation of emulsion · Interaction · Tocopherol

\section{Introduction}

Many foods exist as emulsions which are mixtures of two or more liquids, such as oil and water, that are normally immiscible. Food emulsions include homogenized milk, butter, salad dressing, mayonnaise, and ice cream. An oil-

Eunok Choe

eochoe@inha.ac.kr

1 Department of Food and Nutrition, Inha University, 100 Inharo, Michuhol-gu, Incheon 22212, Republic of Korea in-water $(\mathrm{O} / \mathrm{W})$ emulsion consists of oil droplets dispersed in an aqueous phase; however, a system of water as dispersed (internal) phase and oil as continuous (external) phase forms water-in-oil (W/O) emulsion (McClements, 2008). Multiphase emulsions such as $\mathrm{O} / \mathrm{W} / \mathrm{O}$ and $\mathrm{W} / \mathrm{O} / \mathrm{W}$ are also prepared to protect or release specific ingredients, or produce low-fat foods (Fumiaki et al., 2008; Ito et al., 2012; Serdaroglu et al., 2015; Yoshida et al., 1999). The aqueous phase may contain water-soluble ingredients including sugars and salts, and oil phase may contain a variety of lipid-soluble components such as di- and monoacylglycerols, fatty acids, and tocopherols, whereas surface-active components including phospholipids are distributed in the interfacial region (McClements, 2008). Phospholipids as emulsifiers adsorb at the oil-water interface during the homogenization to prevent phase separation (Laguerre et al., 2017). These components, even at low concentrations, profoundly influence the quality of food emulsions during processing and storage (Traynor et al., 2013).

Quality and shelf-life of food emulsions are determined by their physical and chemical stability referring to an ability to resist changes in spatial distribution and in chemical structure, respectively, of ingredients over time (Mirhosseini et al., 2007). Lipid oxidation is one of the most important chemical reactions determining the chemical stability of food emulsions (Jacobsen, 2016), and many studies to reduce the lipid oxidation have been reported. Addition of antioxidants is the most common way to improve the oxidative stability of lipids in food emulsions, and herb extracts which contain high amounts of polyphenols have received a lot of attention, especially in $\mathrm{O} / \mathrm{W}$ emulsions due to their hydrophilicity. Although there are many reports on the effects of herb extracts on the lipid oxidation (Abdalla and Roozen, 1999; Boroski et al., 2018; 
Frankel et al., 1996; Pawar et al., 2014), not many references have been found on the lipid oxidation in $\mathrm{O} / \mathrm{W}$ emulsions. In addition, the chemistry and implications are still somewhat confusing since herb extracts have various polyphenols with different structures, chemistry, and functional properties. This review intended to provide more clear information on the role and action mechanism of herbs, especially focused on polyphenols, related to the lipid oxidation in food emulsions to help establish new directions for future research and application. Interactions among herbs/polyphenols and between herbs/polyphenols and tocopherols which are naturally derived from edible oil were also discussed.

\section{Lipid oxidation in food emulsions}

Lipid oxidation in food emulsions occurs basically with the same mechanism as in bulk oils (Berton-Carabin et al., 2014), mostly free radical chain reaction including initiation, propagation, and termination steps as follows (Choe and Min, 2006):

$\begin{array}{ll}\text { Initiation } & \mathrm{RH} \rightarrow \mathrm{R}^{\prime}+\mathrm{H}^{\prime} \\ \text { Propagation } & \mathrm{R}+{ }^{3} \mathrm{O}_{2} \rightarrow \mathrm{ROO} \\ & \mathrm{ROO}+\mathrm{R}^{\prime} \mathrm{H} \rightarrow \mathrm{ROOH}+\mathrm{R}^{\prime} \\ \text { Termination } & \mathrm{ROO}+\mathrm{R}^{\prime \prime} \rightarrow \mathrm{ROOR}^{\prime} \\ & \mathrm{R}^{\prime}+\mathrm{R}^{\prime \prime} \rightarrow \mathrm{RR}^{\prime}\end{array}$

Triacylglycerol $(\mathrm{RH})$ molecules in oil should take a radical form (R.) in the initiation step by hydrogen abstraction by heat, metals, and/or light, and R - reacts with atmospheric triplet oxygen $\left({ }^{3} \mathrm{O}_{2}\right)$ to form peroxyl radical (ROO.). The peroxyl radicals abstract hydrogens from another triacylglycerol (R'H) molecules to produce hydroperoxides $(\mathrm{ROOH})$ and another lipid (alkyl) radicals ( R'.). Hydroperoxides are relatively stable at room temperature, but they are decomposed in the presence of heat, light, or metals, and produce low molecular-weight hydrocarbons and carbonyl compounds such as alcohols, aldehydes, and carboxylic acid, by hemolytic scission (Choe and Min, 2006). All radicals produced during the lipid oxidation themselves catalyze the oxidation reaction, especially in the propagation step. When the radicals react each other, non-radical compounds (ROOR', RR') are resulted and there is no more participation in the reaction cycle in the termination step (Choe and Min, 2006).

The lipid oxidation of food emulsions occurs mostly at the water-oil interface rather than the air-oil interface, and is governed by the critical micelle concentration of hydroperoxides and its modification by other amphiphilic compounds (Budilarto and Kamal-Eldin, 2015). The nature of the interface determines the contact among reactants such as oxygen, oil, and metal ions, and thus diffusion is more important in controlling lipid oxidation of the emulsion since it is related with mobility of triacylglycerol molecules inside the oil droplets (Berton-Carabin et al., 2014). Hydroperoxides and free radicals are usually present on the surface of oil droplets and can react with other triacylglycerol molecules, and therefore, the rate of lipid oxidation depends on the speed of these accelerators (hydroperoxides and free radicals) to diffuse within a droplet from one region to another (McClements and Decker, 2000). When surface-active lipid hydroperoxides are accumulated beyond their critical micelle concentration during lipid oxidation, the mechanism for mass transport shifts from the slow transfer of collision-exchange-separation pathway to the fast micelle-assisted mechanism, which may be the transition from the initiation to the propagation step (Laguerre et al., 2017). Under these circumstances, the transfer mechanism for antioxidants changes from diffusion to collision-exchange-separation (Laguerre et al., 2017). Amphiphilic compounds in the $\mathrm{O} / \mathrm{W}$ emulsion arrange themselves to position the polar head groups at the surface and non-polar tails in the interior (Hazahari et al., 2018). Amphiphilic compounds exceeding the critical micelle concentration protect the lipids against oxidation by diluting the substrate or perhaps by replacing lipids at the interface, making it less accessible to radical attack (Ponginebbi et al., 1999). Soy-derived phosphatidylcholine and phosphatidylethanolamine reduced the iron-catalyzed autoxidation of water-in-canola oil (1:1, $\mathrm{w} / \mathrm{w}$ ) emulsion via a physical barrier to oxygen as well as hydrogen donation (Choe and Choe, 2016). The phosphatidylcholine at $250 \mathrm{mg} / \mathrm{kg}$ decreased the photosensitized lipid oxidation of water-in-sunflower oil emulsion $(1: 1, w / w)$ by chemical quenching of singlet oxygen (Lee and Choe, 2011).

There are contrasting reports on the difference in the lipid oxidation rates between emulsions and bulk oils. Lipid oxidation may be more favored in the emulsions than in bulk oils due to the interface which increases contact between oil and prooxidative metal ions or dissolved oxygen in the aqueous phase (Cuvelier et al., 2003; Frankel et al., 2002; Nikovska, 2012). Incorporation of oxygen during homogenization for emulsification was reported to contribute to faster oxidation in emulsions than in bulk oils (Horn et al., 2012). On the other hand, some studies reported no difference (Khan and Shahidi, 2000; McClements and Decker, 2000) and even lower lipid oxidation in the emulsions than in bulk oils (Belhaj et al., 2010). This was suggested to be attributed to slower diffusion of triacylglycerol molecules in the core of oil droplets in the emulsions $\left(10^{-8} \mathrm{~cm}^{2} / \mathrm{s}\right.$ order $)$ than in bulk oils $\left(10^{-7}\right.$ order $)$ (Hennere et al., 2009a; 2009b; Kabri et al., 2013).

Previous reports on the mechanism of lipid oxidation in the emulsions paid attention to transition metal ions in the aqueous phase and the hydroperoxides on the surface of the 
oil droplets. It is well-known that transition metal (iron and copper) ions promote the lipid oxidation by producing radicals. These metal ions in emulsions can be derived from oil and water. Refined soybean oil contains iron and copper at 200 and $2.5 \mu \mathrm{g} / \mathrm{kg}$ (Sleeter, 1981), respectively. Iron and copper levels in drinking-water were reported as $<0.3 \mathrm{mg} / \mathrm{L}$ (WHO, 2003) and in the range from $\leq 0.005$ to $>30 \mathrm{mg} / \mathrm{L}$ (WHO, 2004), respectively. Metal ions react directly with triacylglycerol molecules in oil to produce lipid (alkyl) radicals, decompose hydroperoxides to alkoxyl (RO-) and peroxyl radicals, and produce reactive oxygen species such as superoxide anion radicals $\left(\mathrm{O}_{2} \cdot{ }^{-}\right)$, singlet oxygen $\left({ }^{1} \mathrm{O}_{2}\right)$, and hydroxyl radicals (HO-) as follows (Choe and Min, 2006), and all of which accelerate the lipid oxidation.

$$
\begin{aligned}
& \mathrm{Fe}^{3+}\left(\text { or } \mathrm{Cu}^{2+}\right)+\mathrm{RH} \rightarrow \mathrm{Fe}^{2+}\left(\text { or } \mathrm{Cu}^{+}\right)+\mathrm{R}^{\cdot}+\mathrm{H}^{+} \\
& \mathrm{ROOH}+\mathrm{Fe}^{2+}\left(\text { or }^{+} u^{+}\right) \rightarrow \mathrm{RO}+\mathrm{Fe}^{3+}\left(\text { or } \mathrm{Cu}^{2+}\right)+\mathrm{OH}^{-} \\
& \mathrm{ROOH}+\mathrm{Fe}^{3+}\left(\text { or }^{2+}\right) \rightarrow \mathrm{ROO}^{\cdot}+\mathrm{Fe}^{2+}\left(\text { or } \mathrm{Cu}^{+}\right)+\mathrm{H}^{+} \\
& \mathrm{Fe}^{2+}\left(\text { or } \mathrm{Cu}^{+}\right)+{ }^{3} \mathrm{O}_{2} \rightarrow \mathrm{Fe}^{3+}\left(\text { or } \mathrm{Cu}^{2+}\right)+\mathrm{O}_{2}^{-} \\
& \mathrm{O}_{2}^{--}+\mathrm{O}_{2}^{--}+2 \mathrm{H}^{+} \rightarrow{ }^{1} \mathrm{O}_{2}+\mathrm{H}_{2} \mathrm{O}_{2} \\
& \mathrm{H}_{2} \mathrm{O}_{2}+\mathrm{O}_{2}^{--} \rightarrow \mathrm{HO}+\mathrm{OH}^{-}+{ }^{1} \mathrm{O}_{2}
\end{aligned}
$$

\section{Herb effects on the lipid oxidation of emulsions}

Herbs generally refer to the leafy green or flowering parts of fresh or dried plants valued for their medicinal and savory or aromatic properties, and have been used for flavoring and garnishing foods (Peter and Shylaja, 2004). Basil (Ocimum basilicum), oregano (Origanum vulgare), peppermint (Mentha piperita), rosemary (Rosmarinus officinalis L.), and thyme (Thymus vulgaris) are typical examples of herbs, and many researches on their effects on the lipid oxidation of emulsions have been reported. Rosemary extracts have proven to be effective for controlling lipid oxidation in the corn oil-in-water emulsion (Frankel et al., 1996), and 10\% fish oil-in-water emulsion at $4000 \mathrm{mg} / \mathrm{kg}$ (Erdmann et al., 2015). Lipid oxidative stability of $20 \%$ sunflower oil-in-water emulsion was significantly improved by the addition of sage extract $(600$ and $1200 \mathrm{mg} / \mathrm{kg}$ ) whose antioxidant activity was higher than that of BHT at $300 \mathrm{mg} / \mathrm{kg}$ (Abdalla and Roozen, 1999). Rosemary or thyme extract at $100 \mathrm{mg} / \mathrm{kg}$ decreased the hydroperoxide production in $40 \%$ soybean oil-in-water emulsion (Kim and Choe, 2016). Basil or peppermint extract significantly reduced the production of secondary oxidation products of lipids as well as hydroperoxides in $40 \%$ sunflower oil-in-water emulsion at $100 \mathrm{mg} / \mathrm{kg}$ (Kim and Choe, 2016; Kim et al., 2017) and 25\% olive oil-in- water emulsion (Mihov et al., 2012). Lavender (Lavandula angustifolia) and thyme extracts showed higher antioxidant activity than rosemary extracts in the $\mathrm{O} / \mathrm{W}$ emulsion (Gallego et al., 2013). The antioxidant activity of the peppermint or basil extract at $400 \mathrm{mg} / \mathrm{kg}$ was higher than that of rosemary, oregano, or thyme extract in the $40 \%$ soybean oil-in-water emulsions, and the antioxidant activity showed a concentration dependence within a range between 0 and $400 \mathrm{mg} / \mathrm{kg}$ (Kim and Choe, 2016).

The antioxidant activity derived from herb extracts was different depending on the herb and the extracting solvents; non-polar extracts of barley with $80 \%$ acetone showed higher reducing power than those with $80 \%$ ethanol or methanol and water extracts, whereas the reverse phenomena were observed in hydroxyl or superoxide anion radical scavenging activity and metal chelating activity (Zhao et al., 2006). While the methanol extract of parsley (Petroselinum crispum) at $1000 \mathrm{mg} / \mathrm{kg}$ acted as antioxidant in the lipid oxidation of the $\mathrm{O} / \mathrm{W}$ emulsion, water extract acted as prooxidant. Both the methanol and water extracts of cilantro (Coriandrum sativum) showed prooxidant activity (Wong and Kitts, 2006). Water extract of lemon balm (Melisa officinalis) improved the lipid oxidative stability of olive oil-in-water emulsion at $477 \mathrm{mg} / \mathrm{kg}$ corresponding to the antioxidant activity of BHA at $200 \mathrm{mg} / \mathrm{kg}$ (Poyato et al., 2013). Different antioxidant activity of herbs depending upon the extracting solvents is mainly due to the chemical composition of the extract. Herb extracts mostly contain polyphenols, with less amount of other minor compounds such as tocopherols, carotenoids, and chlorophylls, and non-polar solvents tend to result in less polar components in the extracts. The $75 \%$ ethanol extracts of basil contained 58.3, 3.42, $2(3.25)$, and $3.21 \mathrm{~g} / \mathrm{kg}$ of polyphenols, chlorophylls, carotenoids, and tocopherols, respectively (Kim et al., 2017). Contents of polyphenols, chlorophylls, carotenoids, and tocopherols in the $75 \%$ ethanol extract of peppermint were $169,4.40,0.52$, and $1.32 \mathrm{~g} / \mathrm{kg}$, respectively (Lee and Choe, 2018). Among these compounds, a main contributor to the reduced lipid oxidation of the $\mathrm{O} / \mathrm{W}$ emulsions was high contents of polyphenols, and tocopherols were also very important antioxidant despite low levels; on the other hand, carotenoids and chlorophylls tended to increase the lipid oxidation even in the dark, possibly due to their oxidation products (Lee and Choe, 2018). They suggested that polyphenols could be the first consideration in the herb extracts relating to the lipid oxidation of $\mathrm{O} / \mathrm{W}$ emulsions as antioxidants.

\section{Polyphenol composition of herbs}

Polyphenols are generally defined as compounds having more than 12 phenolic hydroxyl groups (Haslama and Cai, 
1994); however, the definition is generally extended to the compounds exclusively derived from the phenylpropanoid pathway with more than one phenolic unit and deprived of nitrogen-based functions (Bravo, 1998). The phenylpropanoids are a diverse family of organic compounds that are synthesized by plants from phenylalanine and tyrosine. The name is derived from the six-carbon, aromatic phenyl group and the three-carbon propene tail of coumaric acid (Barros et al., 2016; Navarre et al., 2016). Polyphenols protect the plants from environmental stresses such as pathogen attack, UV-irradiation, high temperature/light, wounding, nutrient deficiencies, and herbicide treatment (Solecka, 1997).

The food industry has utilized herbs mostly as flavorings, antioxidants, and preservatives for existing food processing techniques (Giacometti et al., 2018), and polyphenols are the most important in performing these functions. Rosmarinic acid is one of the polyphenol compounds which are the most commonly found in herbs, especially thyme, mugwort (Artemisia vulgaris), peppermint, and basil (Chamila et al., 2003; Kim and Choe 2016; Loughrin and Kasperbauer, 2001; Shan et al., 2005; Zheng and Wang, 2001). The $80 \%$ methanol extract of spearmint (Mentha spicata) is composed of rosmarinic acid and its derivatives $(230.5 \pm 13.5 \mathrm{mg} / \mathrm{g})$ with smaller amounts of salvianolic, caffeoylquinic, hydroxybenzoic, and hydroxycinnamic acids, flavones, and flavanones (Cirlini et al., 2016). Polyphenol composition varies depending on the kind and species of herbs and the polarity of extracting solvents (Dent et al., 2013). This is one of the reasons why studies on the effects of herb extracts on the lipid oxidation of emulsions have reported different behaviors, and the information on the polyphenol composition of herb extracts should be provided in evaluating their anti- or prooxidant activity. The methanol extract of apple mint (Mentha suaveolens) and peppermint contained high amount of quercetin (9.5 and $5.1 \mathrm{mg} / \mathrm{g}$, respectively); however, rutin was abundant in horse mint (Mentha longifolia) and spearmint extract (11.7 and $3.1 \mathrm{mg} / \mathrm{g}$, respectively). Other compounds such as chlorogenic, caffeic, coumaric, ferulic, cinnamic, and rosmarinic acids and epicatechin were present at less than $1 \mathrm{mg} / \mathrm{g}$ in these extracts (Park et al., 2019).

Wojdyło et al. (2007) reported caffeic acid as a major phenolic acid in $80 \%$ methanol extracts of lemon balm, oregano, mugwort, rosemary, and thyme at 8.58, 6.49, $3.04,4.06$, and $5.17 \mathrm{mg} / \mathrm{g}$, respectively. Quercetin in sage (Salvia officinalis) extract $(1.78 \mathrm{mg} / \mathrm{g})$ and luteolin in rosemary extract $(6.16 \mathrm{mg} / \mathrm{g})$ were major flavonoids; however, no flavonoids were detected in oregano, lemon balm, mugwort, and thyme extracts (Wojdyło et al., 2007). Catechin was detected in the $80 \%$ ethanol extracts of rosemary, basil, and peppermint, but much less amount than rosmarinic acid (Kim and Choe, 2016). Isosalvianolic acid A (24.21\%), salvianolic acid B, danshensu, luteolinrutinoside, and luteolin in addition to rosmarinic acid $(35.94 \%)$ were detected in the $80 \%$ ethanol extract of peppermint (Guedon and Pasquier, 1994; Hadjmohammadi et al., 2013; Kim and Choe, 2018).

The polarity of extracting solvents also affects polyphenol composition of the herb extracts. Dent et al. (2013) reported a close relationship of the extraction efficiency of polyphenols with the polarity of solvents; in extracting polyphenols from sage, binary solvent systems of ethanol in water $(30 \%)$ were more efficient than monosolvent system (100\% ethanol or water). Carnosic acid and carnosol were predominant in the methanol or acetone extract of rosemary (467 and $325 \mathrm{~g} / \mathrm{kg}$ ), while they were not found in the water extract (Moreno et al., 2006). Reports on the polyphenol extraction from herbs strongly have suggested that selection of extracting solvents can be very crucial to determine the antioxidant activity of herb extracts in $\mathrm{O} / \mathrm{W}$ emulsions. Table 1 provides the list of polyphenol compounds detected in some of herbs, depending on the extracting solvents.

\section{Roles of polyphenols in the lipid oxidation of emulsions}

Polyphenols have been reported to have antioxidant activity via reactive oxygen species scavenging and/or metal chelating (Choe and Min, 2009). A polar paradox hypothesis on the antioxidant activity of antioxidants focuses the interfacial phenomena, and states that more polar polyphenols are more efficient antioxidants than nonpolar tocopherols in nonpolar systems such as bulk oils (Frankel et al., 1994; Porter et al., 1989). Nonpolar antioxidants are more effective in relatively more polar media, such as O/W emulsions or liposomes (Shahidi and Zhong, 2011). However, other studies particularly with real food systems (mostly O/W emulsions) showed no satisfaction with the polar paradox; polyphenols produce free radicals to accelerate lipid oxidation in emulsions depending on the reaction systems (Eghbaliferiz and Iranshahi, 2016; Zhou and Elias, 2012). Factors to change the role of polyphenols, anti- or prooxidant, in the emulsions include emulsifiers, $\mathrm{pH}$, metals, metal chelators, emulsifiers, and temperature (Medina et al., 2012). For example, (-)-epigallocatechin-3-gallate acted as antioxidant in the flaxseed oil-in-water emulsion at $\mathrm{pH} 7$; however, it was a prooxidant at pH 3 (Zhou and Elias, 2012). The antioxidant activity of caffeic acid was much lower in the Citrem (citric acid ester of mono- and diacylglycerol) stabilized fish oil-in-water emulsion than in the Tween 80 stabilized emulsion and even showed prooxidant activity (Sørensen et al., 2017). Physicochemical characteristics of antioxidants such as polarity may determine their antioxidant 
Table 1 Polyphenol composition of some herb extracts with different solvents

\begin{tabular}{|c|c|c|c|}
\hline Herbs & Extracting solvent & Polyphenols & References \\
\hline \multirow{2}{*}{$\begin{array}{l}\text { Oregano } \\
\text { (Origanum } \\
\text { dictamus })\end{array}$} & Water & $\begin{array}{l}\text { Chlorogenic acid, rutin, luteolin-7- } O \text {-glucoside, apigenin-7- } O \text {-glucoisde, } \\
\text { rosmarinic acid, luteolin }\end{array}$ & Kaliora et al. (2014) \\
\hline & $62.5 \%$ Methanol & $\begin{array}{l}\text { Vanillic acid, protocatechuic acid, syringic acid, gallic acid, cinnamic acid, } o \text { - } \\
\text { coumaric acid, } p \text {-coumaric acid, caffeic acid, chlorogenic acid, rosmarinic } \\
\text { acid, chrysin, epicatechin, naringenin, catechin, genistein, quercetin }\end{array}$ & $\begin{array}{l}\text { Proestos and } \\
\text { Komaitis (2013) }\end{array}$ \\
\hline $\begin{array}{l}\text { Oregano } \\
\text { (O. majoram } \\
\text { L.) }\end{array}$ & Water & $\begin{array}{l}\text { Vanillic acid, protocatechuic acid, syringic acid, gallic acid, cinnamic acid, } o \text { - } \\
\text { coumaric acid, } p \text {-coumaric acid, ferulic acid, caffeic acid, sinapic acid, } \\
\text { rosmarinic acid, chrysin, epicatechin, naringenin, catechin, kaempferol, } \\
\text { quercetin }\end{array}$ & Kaliora et al. (2014) \\
\hline $\begin{array}{l}\text { Oregano } \\
(\text { O. vulgare })\end{array}$ & $50 \%$ Ethanol & $\begin{array}{l}\text { Rosmarinic acid, caffeic acid, protocatechuic acid, } p \text {-coumaric acid, } p \text { - } \\
\text { hydroxybenzoic acid, syringic acid }\end{array}$ & $\begin{array}{l}\text { Vallverdú-Queralt } \\
\text { et al. (2014) }\end{array}$ \\
\hline $\begin{array}{l}\text { Dill } \\
\text { (Anethum } \\
\text { graveolens) }\end{array}$ & $50 \%$ Ethanol & $\begin{array}{l}\text { Chlorogenic acid, } p \text {-hydroxybenzoic acid, caffeic acid, protocatechuic acid, } \\
\text { ferulic acid, } p \text {-coumaric acid, rosmarinic acid, syringic acid }\end{array}$ & $\begin{array}{l}\text { Vallverdú-Queralt } \\
\text { et al. (2015) }\end{array}$ \\
\hline \multirow{4}{*}{$\begin{array}{l}\text { Rosemary } \\
\text { (Rosmarinus } \\
\text { officinalis L.) }\end{array}$} & $80 \%$ Ethanol & $\begin{array}{l}\text { Rutin, catechin, quercetin, gallic acid, ferulic acid, } p \text {-coumaric acid, } p \text {-cinnamic } \\
\text { acid, kaempferol }\end{array}$ & Pereira et al. (2017) \\
\hline & $50 \%$ Ethanol & $\begin{array}{l}\text { Rosmarinic acid, } p \text {-hydroxybenzoic acid, caffeic acid, protocatechuic acid, } p \text { - } \\
\text { coumaric acid, syringic acid, ferulic acid, quercetin, chlorogenic acid }\end{array}$ & $\begin{array}{l}\text { Vallverdú-Queralt } \\
\text { et al. (2014) }\end{array}$ \\
\hline & Methanol & Luteolin, caffeic acid, apigenin, ferulic acid & Wojdyło et al. (2007) \\
\hline & $\begin{array}{l}\text { Acetonitrile with } \\
\text { formic acid }(2 \%)\end{array}$ & $\begin{array}{l}\text { Carnosic acid, carnosol, rosmanol, hispidulin-rutinoside, apigenin, hesperidin, } \\
\text { rosmarinic acid, luteolin, }\end{array}$ & Mena et al. (2016) \\
\hline \multirow{2}{*}{$\begin{array}{l}\text { Thyme } \\
\text { (Thymus } \\
\text { vulgaris) }\end{array}$} & $50 \%$ Ethanol & Rosmarinic acid, caffeic acid, $p$-hydroxybenzoic acid, protocatechuic acid & $\begin{array}{l}\text { Vallverdú-Queralt } \\
\text { et al. (2014) }\end{array}$ \\
\hline & Methanol & Caffeic acid, ferulic acid & Wojdyło et al. (2007) \\
\hline \multirow{4}{*}{$\begin{array}{l}\text { Peppermint } \\
\text { (Mentha } \\
\text { piperita) }\end{array}$} & Acetonitrile & $\begin{array}{l}\text { Eriocitrin, rosmarinic acid, luteolin-7-O-glucoside, hesperidin, eriodictyol, } \\
\text { isorhoifolin, caffeic acid, luteolin }\end{array}$ & Dorman et al. (2009) \\
\hline & Methanol & $\begin{array}{l}\text { Rosmarinic acid, eriocitrin, luteolin-7-O-glucoside, hesperidin, isorhoifolin, } \\
\text { luteolin }\end{array}$ & Dorman et al. (2009) \\
\hline & Water & Rosmarinic acid, luteolin-7-O-glucoside, eriocitrin & Dorman et al. (2009) \\
\hline & $\begin{array}{l}\text { Methanol-ethanol } \\
\quad(1: 1)\end{array}$ & $\begin{array}{l}\text { Chlorogenic acid, rutin, caffeic acid, 4-hydroxybenzoic acid, ferulic acid, } \\
\text { vanillic acid }\end{array}$ & Farnad et al. (2014) \\
\hline \multirow{2}{*}{$\begin{array}{l}\text { Sage } \\
\text { (Salvia } \\
\text { officinalis) }\end{array}$} & Water & $\begin{array}{l}\text { Apigenin, luteolin-7-O-glucuronide, rosmarinic acid, salvianolic acid, sagerinic } \\
\text { acid, scuttelarein, saponarin }\end{array}$ & $\begin{array}{l}\text { Afonso et al. (2019), } \\
\text { Walch et al. (2011) }\end{array}$ \\
\hline & Methanol & Rosmarinic acid, carnosic acid, salvianolic acid B and A, caffeic acid & Fotovvat et al. (2018) \\
\hline
\end{tabular}

activity; propyl gallate which is non-polar is concentrated at the oil-water interface in the emulsion and preferentially donates hydrogen to lipid radicals rather than metal chelation in the aqueous phase (Aaneby, 2012). Different roles of the same polyphenol compound under specific conditions have been explained with diverse mechanisms, which is described in the following sections.

\section{As antioxidants}

The antioxidant activity of polyphenols is resulted from scavenging reactive oxygen species including hydroxyl, peroxyl and alkyl radicals, chelating prooxidative metals, and decomposing lipid peroxides (García-Pérez et al., 2018; Kurek-Górecka et al., 2014). Hydroxytyrosol and oleuropein improved the oxidative stability of lipids in an
O/W emulsion through a complex formation with prooxidative copper in addition to scavenging radicals (PaivaMartins et al., 2006). Polyphenols contain one or more aromatic rings bearing at least two hydroxyl groups in their structures, and thus can easily donate phenolic hydrogen to radicals, which is related to the reduction potential. Reduction potentials of 3,5-dihydroxyanisol ( $0.84 \mathrm{~V}), 2,4-$ dihydroxyacetophenone $\quad(0.89 \mathrm{~V}), \quad$ 2-methoxy-4methylphenol $(0.68 \mathrm{~V})$, catechol $(0.53 \mathrm{~V})$, 4-methylcatechol $(0.52 \mathrm{~V})$, and methyl gallate $(0.56 \mathrm{~V})$ radicals were lower than that of alkyl and peroxyl radicals of lipids (1.06 V) (Jovanovic et al., 1996). Although phenoxyl radicals (PO) from polyphenols $(\mathrm{POH})$ are produced, their resonance structures (Fig. 1) enable them to be more stable than alkyl, peroxyl, or alkoxyl radicals of lipids produced during lipid oxidation. When phenoxyl radicals 
Fig. 1 Resonance structures of phenoxyl radical

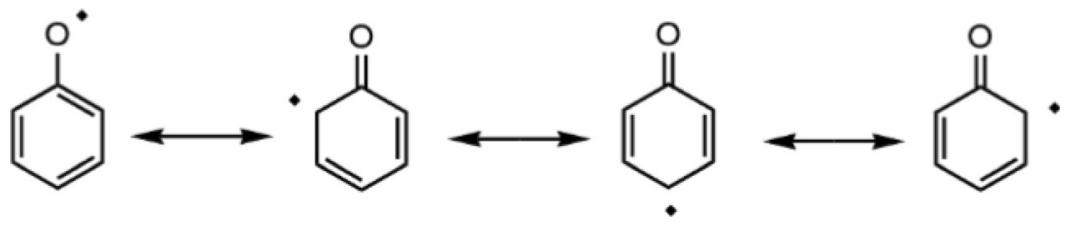

combine together to form dimers (POOP), the chain reaction can be terminated (Mahoney and Weiner, 1972). Some of polyphenol dimers even show enhanced antioxidant activity; the superoxide anion radical scavenging capacity of ferulic acid dimers were higher at $\mathrm{pH} 7.4$ than that of ferulic acid, and the order of scavenging activity was 5-5diferulic acid $>8$ - $O$-4-diferulic acid $>8$-8-diferulic acid (Cano et al., 2002).

$$
\begin{aligned}
& \mathrm{ROO}^{\circ}+\mathrm{POH} \rightarrow \mathrm{ROOH}+\mathrm{PO} \\
& \mathrm{R}^{\circ}+\mathrm{POH} \rightarrow \mathrm{RH}+\mathrm{PO} \\
& \mathrm{RO}^{\circ}+\mathrm{POH} \rightarrow \mathrm{ROH}+\mathrm{PO} \\
& \mathrm{PO}+\mathrm{PO} \rightarrow \mathrm{POOP}
\end{aligned}
$$

Radical scavenging activities of polyphenols depend on the chemical structure and distribution in each phase of an emulsion, the oil, interfacial, and aqueous regions (GarcíaPérez et al., 2018). Since polyphenols produce phenoxyl radicals upon hydrogen donation to scavenge various lipid radicals, the stability of the phenoxyl radicals determine the efficiency of polyphenols as antioxidants; the higher the stability of the phenoxyl radical is, the more efficient the polyphenol is. The phenoxyl radical can be stabilized by intramolecular hydrogen bonds and the extended delocalization and conjugation of the electrons enhanced by resonance phenomena (Chen et al., 2015). Polyphenols with low ionization potential and $\mathrm{O}-\mathrm{H}$ bond dissociation energy are expected to have high radical scavenging activity (AlSehemi and Irfan, 2017). The phenoxyl radical is further stabilized by substitution with bulky $o$-substituents, coordination to metal ions or $p$-conjugation expansion (Aotake et al., 2015). Phenoxyl radicals having hydroxyl groups at $o$ - and/or $p$-position derived from diphenols are more stable than those at $m$-position as shown in Fig. 2. In addition to the substituent position, kinds of substituent groups in the benzene ring affect the radical scavenging activity of polyphenols. The electron-withdrawing groups increase the ionization potential and $\mathrm{O}-\mathrm{H}$ bond dissociation energy, and thus decrease the radical scavenging activity (Zheng et al., 2018). The electron-donating substituents show an opposite behavior. Catechol (o-hydroxyphenol) reacts with lipid radicals faster than $o$ methoxyphenols (O-methylated catechol) due to higher stability of their semiquinone radicals upon hydrogen donation (Aaneby, 2012). The oxygen atom of the methoxyl and hydroxyl groups in the structure has lone pair electrons, and resulting $\mathrm{p}-\pi$ conjugation will increase the electron cloud density of the benzene ring, and will decrease the energy of $\pi-\pi^{*}$ electron transition (Gao et al., 2015). o-Methoxyphenols possess lower capacity for electron and hydrogen atom donation than catechols, which suggests higher radical scavenging activity of catechols. In addition, the formation of quinone upon a second electron donation becomes slow in o-methoxyphenols, and thus reduces the radical scavenging activity (Lemanska et al., 2004).

Lipid radical scavenging activities of polyphenols are higher when they are more distributed in the interfacial region (Losada-Barreiro et al., 2013a) at which lipid radical production occurs mostly (Freiría-Gándara et al., 2018). Polyphenols are predominantly located in the water-interfacial regions rather than in the oil droplet interior; meanwhile, more hydrophobic tocopherols are mostly located in the oil-interfacial regions (Lisete-Torres et al., 2012; Losada-Barreiro et al., 2013b). For the radical scavenging activity, the antioxidants should be transferred to the oil molecules, whose mechanism is affected by their hydrophobicity. Transfer of hydrophilic antioxidants from one oil droplet to another occurs mainly via diffusion through the water phase, while hydrophobic antioxidants are transferred by collision-exchange-separation process (Laguerre et al., 2017). Below a hydrophobicity threshold, the antioxidants are located in the water phase not close enough to the interfacial region, resulting in weaker antioxidant capacity. However, at and beyond the hydrophobicity threshold, the antioxidants are located at the interface and within the oil phase, respectively (Laguerre et al., 2017). The polarity of polyphenols is related with their solubility in the water phase, and affects their concentration at the interfacial region. Methyl carnosate (150-300 $\mu \mathrm{M})$, whose partition coefficient for the oil phase to the water phase is $23.4 \pm 2.3$, was more located at the oil-water interfaces and in the oil phase, and was a more effective antioxidant than more polar carnosic acid (partition coefficient, $10.2 \pm 1.1$ ) in a corn oil-in-water emulsion (10:90, w/w) (Huang et al., 1996). Although the hydrophobicity of polyphenols affects their distribution in each phase of the emulsion, this is not always true; hydrophilic gallic or caffeic acid was more distributed in the interfacial region of emulsions than hydrophobic lauryl gallate, partly due to an emulsifier (Losada-Barreiro et al., 2014). They reported that an increase in the concentration 
<smiles>CC1C[C@H]1C1(O)C=CC=CC1(O)c1ccccc1[O-]</smiles>

o-diphenol

(most stable)

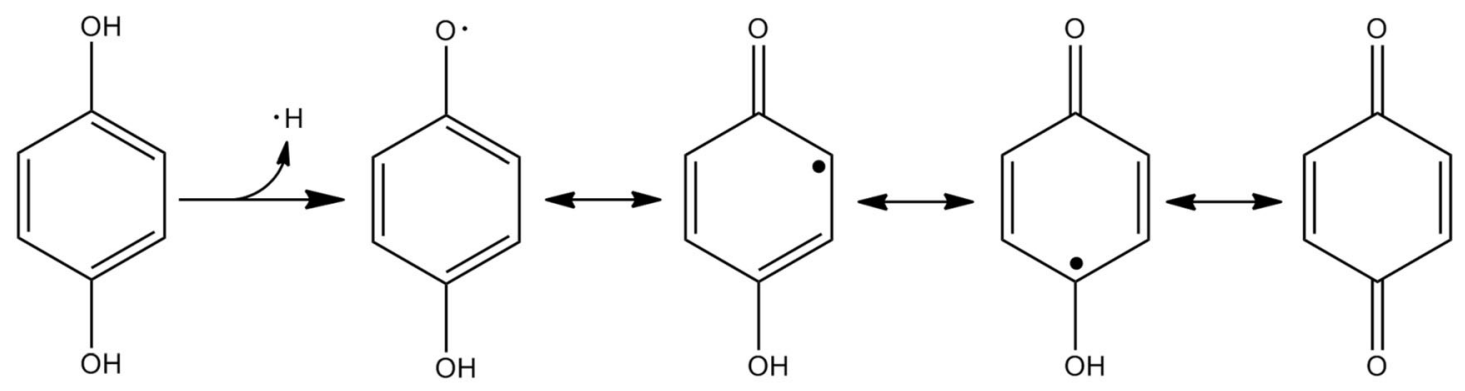

-diphenol

(most stable)<smiles>CC(C)C=CC=CC=C1C=CC(O)=CC1=O</smiles>

$m$-diphenol

(unstable)

Fig. 2 Resonance structures of diphenol upon hydrogen abstraction

of Tween 20 promoted the distribution of resveratrol in the interfacial region of the corn oil emulsions.

Antioxidant activity of polyphenols can be resulted from chelation of prooxidative metals. Ferrous $\left(\mathrm{Fe}^{2+}\right)$, ferric $\left(\mathrm{Fe}^{3+}\right)$, cuprous $\left(\mathrm{Cu}^{+}\right)$, and cupric $\left(\mathrm{Cu}^{2+}\right)$ ions are one of the leading causes to produce strong oxidants such as hydroxyl and peroxyl radicals (Kim and Choe, 2018). The $\mathrm{Fe}^{2+}$ is more active than $\mathrm{Fe}^{3+}$ in catalyzing the lipid autoxidation (Halliwell and Gutteridge, 2001; Mei et al., 1998). By chelating these metal ions, polyphenols help to reduce the formation and implication of the reactive oxygen species in the lipid oxidation of the emulsion. In addition, metal chelates (metal-polyphenol complex) are more prone to scavenge free radicals than the free polyphenols (Cherrak et al., 2016). Catechol or galloyl moieties in the structure of polyphenols are the responsible part for the complex formation with metal ions (Andjelkovica et al., 2006); double deprotonation in the hydroxyl group of catechol ligands leads to the binding of catechol to the $\mathrm{Fe}^{3+}$ (Fig. 3) (Cass, 2014). It was reported that ligands preferred a bridged bidentate mode of coordination (Pandey et al., 2019), and Xu (2013) suggested double (bis-) and triple (tris-) complex formation between catechol and iron (Fig. 4). The 3-hydroxy-4-keto group in flavonols and the 5,6,7-trihydroxyl group in flavones were reported to be the most efficient copper chelation sites in flavonoids (Ríha et al., 2014). The iron-chelating ability of protocatechuic acid, hydroxytyrosol, gallic acid, caffeic 


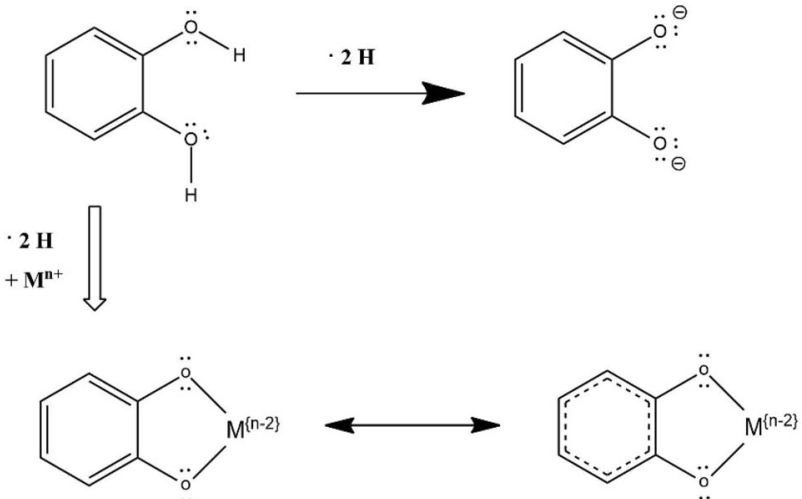

Fig. 3 Mechanism for the catechol-metal complex formation (from Cass, 2014)
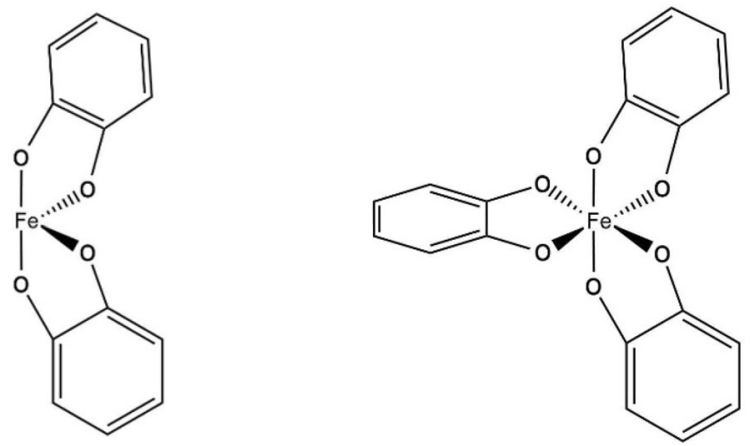

Fig. 4 Examples of the coordination of two and three 2-ligands to iron (from Xu, 2013)

acid, and chlorogenic acid was reported to be $1.43,2.66$, $4.78,8.12$, and 20.13/M, respectively (Andjelkovića et al., 2006). The $\mathrm{Fe}^{3+}$ complex formation of epigallocatechin gallate and epicatechin gallate was lower than that of epigallocatechin and catechin due to the electron-withdrawing effect of the esters (Jovanovic et al., 1998). Complex formation of polyphenols with iron is dependent on their concentration and the $\mathrm{pH}$ (Kim and Choe, 2018), and caffeic acid needs to be usually at higher than $50 \mu \mathrm{M}$ in vicinity of free radicals generated at the oil phase (Aaneby, 2012). Although caffeic acid having carboxyl group possesses a polar character, it becomes less polar at $\mathrm{pH} 3.5$ due to protonation of the group, which may facilitate accessibility of caffeic acid at the interfacial region (Kristinová et al., 2009). Epigallocatechin gallate and gallic acid formed a complex with $\mathrm{Cu}^{2+}$, dominantly above neutral $\mathrm{pH}$, which appreciably contributes to the metal speciation (Pirker et al., 2012).

\section{As prooxidants}

In spite of the antioxidant activity of polyphenols, some of polyphenols show prooxidant activity under certain conditions such as at high concentration, and their interaction with metal ions can increase the lipid oxidation (Yordi et al., 2012). The prooxidant activities of polyphenols are derived from their autoxidation, in which semiquinone and superoxide anion radicals are produced. Polyphenols having either a pyrogallol or catechol structure such as quercetin and catechin can generate reactive oxygen species such as superoxide anion radicals, hydrogen peroxides, and peroxyl radicals as shown in Fig. 5 (Shishido et al., 2018). Pyrogallol-type flavonoids generate more hydrogen peroxides than the catechol-types (Miura et al., 1998). The prooxidant activities of polyphenols are also derived from the reduction of $\mathrm{Fe}^{3+}$ to more reactive $\mathrm{Fe}^{2+}$ (Zeraik et al., 2014). Gallic acid increased the hydroperoxide decomposition in a fish oil emulsion by reducing metal ions (Jacobsen et al., 2001). Figure 6 shows a complex formation of caffeic acid with $\mathrm{Fe}^{3+}$ which subsequently produces $o$-hydroxyphenoxyl radical through an intramolecular electron transfer reaction. The $o$-hydroxyphenoxyl radical is transformed to $o$-semiquinone anion radical upon hydrogen abstraction, and the $o$-semiquinone anion radical finally produces $o$-quinone upon release of $\mathrm{Fe}^{2+}$ (Aaneby, 2012; Kristinová et al., 2009).

The prooxidant activities of polyphenols are related with their redox potential; polyphenols with high oxidation potential $(>0.45 \mathrm{~V})$ such as salicylic, hydroxybenzoic, vanillic, syringic, and coumaric acids, were reported to act as prooxidants at $4 \mathrm{mM}$ (Simić et al., 2007). Besides their oxidizability, hydrophobicity can be a decisive factor; esterification of protocatechuic acid increased the prooxidant capacity (Zeraik et al., 2014). Concentration of polyphenols also affects the prooxidant activity; caffeic acid showed a maximum prooxidative effect at $25-50 \mu \mathrm{M}$ in a herring oil-in-water (10:90, w/w) emulsion (Aaneby, 2012). Compared to many reports on the antioxidant activity of polyphenols, there are limited number of researches on the prooxidant activity and factors so far, which requires more research.

\section{Interactions among herbs/polyphenols in the lipid oxidation of emulsions}

Polyphenols show different activities depending on their structure, concentration, and distribution as described previously, and the method to evaluate the antioxidant activity may also give different results (Sonam and Guleria, 2017). For this reason, it is not easy that the antioxidant activity of polyphenol mixture is predicted simply from that of pure compounds, and it is true for their interaction (Katalinic, 2015). It is also possible that one dose combination produces synergistic interactions while the another produces antagonism with the same substances (Pan et al., 2018; Sonam and Guleria, 2017). 
<smiles>CC(O)[C@H](C)O[C@H](C)C(=O)O</smiles>

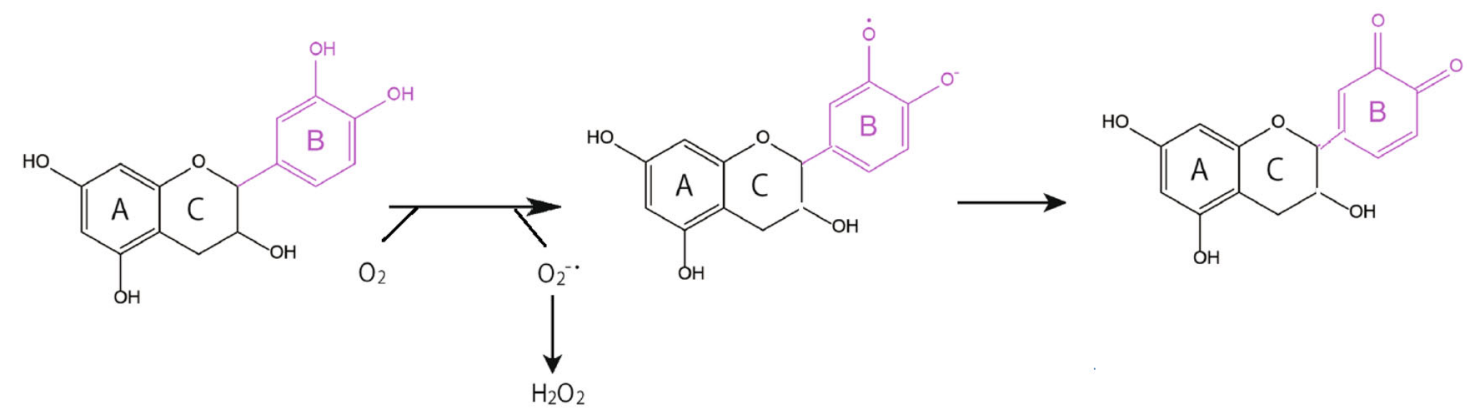

Fig. 5 Oxidation of catechin and coupled generation of reactive oxygen species (modified from Shishido et al., 2018)

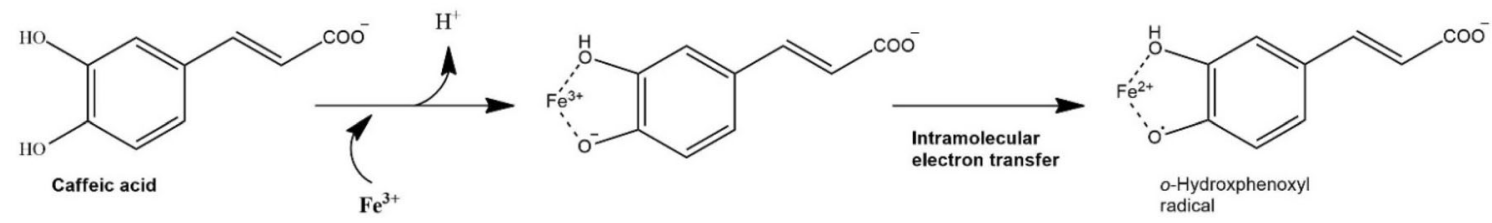

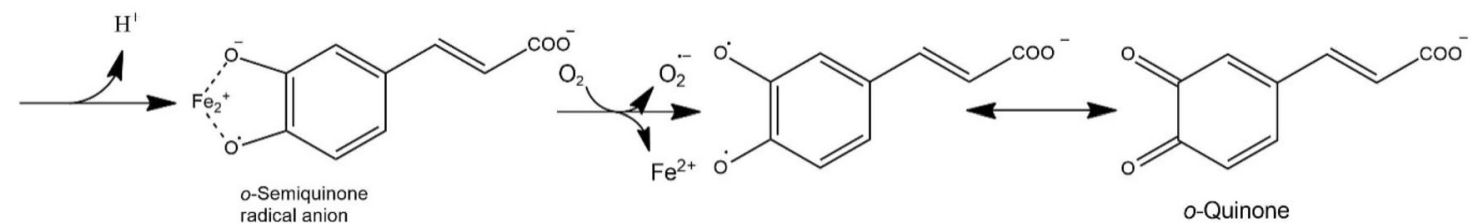

Fig. 6 Mechanism for the reduction of Fe(III) to Fe(II) by caffeic acid (from Aaneby 2012; Kristinová et al., 2009)

Thyme showed a synergistic antioxidant activity with coriander (Coriandrum sativum) and celery (Apium graveolens) (Crespo et al., 2019), which can help to avoid undesirable side effects due to higher doses of one single herb (Jain et al., 2011). Synergism occurs when a stronger antioxidant is protected by a weaker one by regeneration or sacrificial oxidation and/or when 2 or more antioxidants with different antioxidant mechanisms are combined together (Choe and Min, 2009). Hot water extracts of green tea showed a synergistic interaction with clove basil (Ocimum gratissimum) to reduce lipid oxidation at the combination ratio of 1:1, 1:2, 1:3, 3:1, and 2:1 (Farooq and Sehgal, 2019). Synergistic interactions among polyphenols were shown; quercetin showed synergism with phloretin and epicatechin $(1 \mu \mathrm{M}$ each $)$ in the $\mathrm{Cu}^{2+}$-mediated oxidation of human low density lipoproteins (Yeomans et al.,
2005). Rosmarinic acid showed synergistic effects with quercetin and caffeic acid in the AAPH-induced oxidation of linoleic acid emulsions (Peyrat-Maillard et al., 2013). Synergistic antioxidant activity is dependent on the type of antioxidant and its concentration, and thus the appropriate concentration and combination of antioxidants may be important factors for the maximum synergism (Sonam and Guleria, 2017).

Antagonism has been known to arise by regeneration of the less effective antioxidant by the more effective one, oxidation of the more effective antioxidant by the less effective antioxidant radicals, competition between antioxidant radical adduct formation and the antioxidant regeneration, and alteration of microenvironment of one antioxidant by another (Choe and Min, 2009). Moderate antagonism was shown in the DPPH radical scavenging 
activity between hot water extracts of green tea and clove basil at the ratio of 1:2 (Farooq and Sehgal, 2019). Caffeic acid showed antagonistic effects with the $(+)$-catechin or quercetin in equimolar proportions in the AAPH-induced oxidation of linoleic acid emulsions (Peyrat-Maillard et al., 2013). Meanwhile, Olszowy et al. (2019) suggested that the antagonism caused by the change in radical neutralization ability of antioxidants could be due to the effect of different reaction kinetics between a given antioxidant and the ABTS cation radical. Therefore, it should be considered that antagonism may be derived from a reaction between polyphenols and radicals used in evaluating the antioxidant activity rather than mutual interaction between individual polyphenols.

\section{Effects of tocopherols on the antioxidant activity of herbs/polyphenols in the lipid oxidation of emulsions}

The anti- or prooxidant activities of herb extracts or polyphenols depend on the oxidation conditions as described previously, and other components present in the emulsion such as proteins and antioxidants other than polyphenols also affect the activities. Polyphenols derived from the aqueous extract of roselle (Hibiscus sabdariffa) showed high protection against lipid oxidation of the whey spread emulsion via a dimer formation with whey proteins (Chikhoune et al., 2017). Rice glutelin enhanced the antioxidant activity of procyanidin via formation of molecular complexes primarily through hydrophobic attractive forces (Dai et al., 2019). The exposed sites of protein upon breaking its hydrogen bonds are important binding sites for polyphenols (Siebert et al., 1996).

Since interactions between polyphenols and protein or peptides are mostly limited to meat and fish products, tocopherols which are commonly derived from edible oils are more important concerning the interaction with polyphenols in food emulsions. Lipid oxidation of the soybean oil-in-water $(4: 6, \mathrm{w} / \mathrm{w})$ emulsion with added ethanol extract of peppermint at $400 \mathrm{mg} / \mathrm{kg}$ was lower in the co-presence of $\gamma$ - or $\delta$-tocopherol at $600 \mathrm{mg} / \mathrm{kg}$; however, an opposite result was shown in the emulsion with $\alpha$ tocopherol (Kim and Choe, 2019). However, co-addition of rosemary extract and tocopherols in meat products did not increase the antioxidant efficacy of these individually used compounds (Resurreccion and Reynolds, 1990). Caffeic acid at $100 \mu \mathrm{M}$ was very efficient antioxidant in fish oil-inwater emulsion $(\mathrm{pH} \mathrm{7})$ in the presence of endogenous tocopherols, while it was a prooxidant without tocopherols (Sørensen et al., 2017). Quercetin at $1 \mu \mathrm{M}$ showed a significant $(p<0.001)$ synergism with $\alpha$-tocopherol at $5 \mu \mathrm{M}$; however, there was no interaction observed from epicatechin, hesperetin, or phloretin with $\alpha$-tocopherol (Yeomans et al., 2005). Rosmarinic acid showed synergism with $\alpha$ tocopherol in reducing lipid oxidation of the $\mathrm{O} / \mathrm{W}$ emulsions, via additional formation of caffeic acid from rosmarinic acid; rosmarinic acid alters the formation of $\alpha$ tocopherol quinone, and $\alpha$-tocopherol increases the formation of caffeic acid from rosmarinic acid (Panya et al., 2012). Caffeic acid formation from rosmarinic acid was also shown during the iron-catalyzed oxidation of soybean oil-in-water emulsion with added peppermint extract at $\mathrm{pH}$ 6.0 (Kim and Choe, 2018). Esterification of the carboxyl group in polyphenols decreases the solubility in water and alters the interaction with tocopherols. The synergistic effect of rosmarinic acid with $\alpha$-tocopherol was decreased by esterification, and the eicosyl esters of rosmarinic acid even showed slightly antagonistic interaction with $\alpha$-tocopherol (Panya et al., 2012).

Synergisms of polyphenols with tocopherols are explained with several mechanisms. Polyphenols protect tocopherols by chelating prooxidative metals (Kurek-Górecka et al., 2014), or forming non-covalent complexes which enable regeneration of tocopherols (Fabre et al., 2015). It was also suggested that co-presence of tocopherols in the emulsion containing herb extracts can shift a major role of polyphenols as antioxidants from scavenging lipid peroxyl radicals to tocopheryl radical scavenging (Kim and Choe, 2019), which can regenerate tocopherols. Regeneration of $\alpha$-tocopherol by polyphenols via hydrogen donation to the tocopheryl radical was also shown in the rosemary extracts (Fang and Wada, 1993; Wada and Fang, 1992; Wong et al., 1995). The ability of polyphenols to act as a defense agent by donating an electron to tocopherols critically depends on the reduction potentials of their radicals. Polyphenols with a lower redox potential than tocopherols $(0.500 \mathrm{~V})$ can donate electrons to tocopheryl radicals to regenerate tocopherols (Choe and Min, 2009). The reduction potential of $(+)$-catechin, (-)-epicatechin, (-)-epigallocatechin, (-)-epicatechin gallate, (-)-epigallocatechin gallate was reported to be $0.281,0.277,0.287$, $0.098 \sim 0.146$, and $0.104 \sim 0.153 \mathrm{~V}, \quad$ respectively (Baranowska et al., 2018), which enables electron donation from these polyphenols to tocopheryl radicals. Instead of protection of polyphenols on tocopherols, tocopherols may protect polyphenols from degradation depending on tocopherol homologs; $\gamma$ - and $\delta$-tocopherols at $600 \mathrm{mg} / \mathrm{kg}$ lowered polyphenol degradation in soybean oil-in-water emulsion with added ethanol extract of peppermint (400 mg/kg), but $\alpha$-tocopherol increased polyphenol degradation (Kim and Choe, 2019).

On the contrary to the synergistic effects, the antagonistic effects were observed between $\alpha$-tocopherol and caffeic acid and between $\alpha$-tocopherol and rosmarinic acid in the AAPH-induced oxidation of linoleic acid emulsions (Peyrat-Maillard et al., 2013). They also suggested that in 
the co-presence of $\alpha$-tocopherol, rosmarinic acid acts as a lipid radical scavenger rather than tocopheryl radical scavenger. The above discussion on the interaction between herb polyphenols and tocopherols suggests that tocopherols generally show synergistic antioxidant activities with herb polyphenols, partly depending on their homologs and oxidation environments, and the protection of tocopherols from degradation or their regeneration by polyphenols is an important protection mechanism.

It is true that studies on the interactions of polyphenols derived from herbs with tocopherols from oils are still within the limited area due to diverse environmental factors affecting their activities. Therefore, more research, including kinetics among phenoxyl radicals, lipid radicals, and tocopheryl radicals under various conditions, is required for the highly stable food emulsions with herbs.

Acknowledgments This work was supported by INHA UNIVERSITY Research Grant (\#63071).

\section{Compliance with ethical standards}

Conflict of interest The author declares no conflict of interest.

Open Access This article is licensed under a Creative Commons Attribution 4.0 International License (https://creativecommons.org/ licenses/by/4.0/), which permits use, sharing, adaptation, distribution and reproduction in any medium or format, as long as you give appropriate credit to the original author(s) and the source, provide a link to the Creative Commons licence, and indicate if changes were made. The images or other third party material in this article are included in the article's Creative Commons licence, unless indicated otherwise in a credit line to the material. If material is not included in the article's Creative Commons licence and your intended use is not permitted by statutory regulation or exceeds the permitted use, you will need to obtain permission directly from the copyright holder. To view a copy of this licence, visit http://creativecommons.org/licenses/ by/4.0/

\section{References}

Aaneby J. Iron Catalyzed Lipid Oxidation in Emulsions and the Influence of Antioxidants. pp. 57-58. Master thesis, Norwegian University of Science and Technology, Trondheim, Norway (2012)

Abdalla AE, Roozen JP. Effect of plant extracts on the oxidative stability of sunflower oil and emulsion. Food Chem. 64: 323-329 (1999)

Afonso AF, Pereira OR, Fernandes Â, Calhelha RC, Silva AMS, Ferreira ICFR, Cardoso SM. Phytochemical composition and bioactive effects of Salvia africana, Salvia officinalis 'Icterina' and Salvia mexicana aqueous extracts. Molecules 24: 4327 (2019). https://doi.org/10.3390/molecules 24234327

Al-Sehemi AG, Irfan A. Effect of donor and acceptor groups on radical scavenging activity of phenol by density functional theory. Arab. J. Chem. 10: S1703-S1710 (2017)

Andjelkovića M, Van Camp J, De Meulenaerb B, Depaemelaerea G, Socaciud C, Verloo M, Verhe R. Iron-chelation properties of phenolic acids bearing catechol and galloyl groups. Food Chem. 98: 23-31 (2006)
Aotake T, Suzuki M, Aratani N, Yuasa J, Kuzuhara D, Hayashi H, Nakano H, Kawai T, Wu J, Yamada H. 9,9'-Anthryl-anthroxyl radicals: strategic stabilization of highly reactive phenoxyl radicals. Chem. Commun. 51: 6734-6737 (2015)

Baranowska M, Suliborska K, Chrzanowski W, Kusznierewicz B, Namieśnik J, Bartoszek A. The relationship between standard reduction potentials of catechins and biological activities involved in redox control. Redox Biol. 17: 355-366 (2018)

Barros J, Serrani-Yarce JC, Chen F, Baxter D, Venables BJ, Dixon RA. Role of bifunctional ammonia-lyase in grass cell wall biosynthesis. Nat. Plants 2: 16050 (2016). https://doi.org/10. 1038/nplants.2016.50

Belhaj N, Arab-Tehrany E, Linder M. Oxidative kinetics of salmon oil in bulk and in nanoemulsion stabilized by marine lecithin. Process Biochem. 45: 187-195 (2010)

Berton-Carabin CC, Ropers M-H, Genot C. Lipid oxidation in oil-inwater emulsions: Involvement of the interfacial layer. Comp. Rev. Food Sci. Food Saf. 13: 945-977 (2014)

Boroski M, Aguiar AC, Rotta EM, Bonafe EG, Valderrama P, Souza NE, Visentainer JV. Antioxidant activity of herbs and extracted phenolics from oregano in canola oil. Intern. Food Res. J. 25: 2444-2452 (2018)

Bravo L. Polyphenols: Chemistry, dietary sources, metabolism, and nutritional significance. Nutr. Rev. 56: 317-333 (1998)

Budilarto ES, Kamal-Eldin A. The supramolecular chemistry of lipid oxidation and antioxidation in bulk oils. Eur. J. Lipid Sci. Technol. 117: 1095-1137 (2015)

Cano A, Arnao MB, Williamson G, Garcia-Conesa M-T. Superoxide scavenging by polyphenols: effect of conjugation and dimerization, Redox Report 7: 379-383 (2002)

Cass ME. More Information about the [Tris(catecholato)Iron(III) $]^{3-}$ anion (2014). Available from: https://people.carleton.edu/ $\sim$ mcass/TrisChelates/jsmol/MTC-MI-C2js.html. Accessed 16 Feb 2020

Chamila J, Naohiro G, Tomoko A, Shun W. Phenolics composition and antioxidant activity of sweet basil (Ocimum basilicum L). J. Agr. Food Chem. 51: $4442-4449$ (2003)

Chen Y, Xiao H, Zheng J, Liang G. Structure-thermodynamicsantioxidant activity relationships of selected natural phenolic acids and derivatives: An experimental and theoretical evaluation. PLoS ONE 10: e0121276. https://doi.org/10.1371/journal.pone.0121276 (2015)

Cherrak SA, Mokhtari-Soulimane N, Berroukeche F, Bensenane B, Cherbonnel A, Merzouk $\mathrm{H}$, Elhabiri $\mathrm{M}$. In vitro antioxidant versus metal ion chelating properties of flavonoids: A structureactivity investigation. PLoS ONE 11: e0165575 (2016). https:// doi.org/10.1371/journal.pone.0165575

Chikhoune A, Gagaoua M, Nanema KD, Souleymane AS, Hafid K, Aliane K, Hadjal S, Madani K, Sentandreu E, Sentandreu MÁ, Boudjellal A, Križman M, Vovk I. Antioxidant activity of Hibiscus sabdariffa extracts incorporated in an emulsion system containing whey proteins: Oxidative stability and polyphenolwhey proteins interactions. Arab. J. Sci. Eng. 42: 2247-2260 (2017)

Choe E, Min DB. Mechanisms and factors for edible oil oxidation. Comp. Rev. Food Sci. Food Saf. 5: 169-186 (2006)

Choe EO, Min DB. Mechanisms of antioxidants in the oxidation of foods. Comp. Rev. Food Sci. Food Saf. 8: 345-358 (2009)

Choe J, Choe E. Effect of soy-derived phospholipid on the autoxidation of canola oil in a water/oil emulsion. J. Am. Oil Chem. Soc. 93: 1085-1094 (2016)

Cirlini M, Mena P, Tassotti M, Herrlinger KA, Nieman KM, Dall'Asta C, Del Rio D. Phenolic and volatile composition of a dry spearmint (Mentha spicata L.) extract. Molecules. 21: 1007 (2016). https://doi.org/10.3390/molecules21081007 
Crespo Y A, Sánchez LRB, Quintana YG, Cabrera AST, del Sol AB, Mayancha DMG. Evaluation of the synergistic effects of antioxidant activity on mixtures of the essential oil from Apium graveolens L., Thymus vulgaris L. and Coriandrum sativum $\mathrm{L}$. using simplex-lattice design. Heliyon 5: e01942 (2019). https:// doi.org/10.1016/j.heliyon.2019.e01942

Cuvelier ME, Lagunes-Galvez L, Berset C. Do antioxidants improve the oxidative stability of oil-in-water emulsions? J. Am. Oil Chem. Soc. 80: 1101-1105 (2003)

Dent M, Dragovic-Uzelac V, Penic M, Brncic M, Bosiljkov T, Levaj B. The effect of extraction solvents, temperature and time on the composition and mass fraction of polyphenols in Dalmatian wild sage (Salvia officinalis L.) extracts. Food Technol. Biotechnol. 51: 84-91 (2013)

Dai T, Chen J, McClements DJ, Hu P, Ye X, Liu C, Li T. Proteinpolyphenol interactions enhance the antioxidant capacity of phenolics: analysis of rice glutelin-procyanidin dimer interactions. Food Funct. 10: 765-774 (2019)

Dorman HJD, Koşar M, Başer KHC, Hiltunen R. Phenolic profile and antioxidant evaluation of Mentha x piperita L. (Peppermint) extracts. Nat. Product Commun. 4: 535-542 (2009)

Eghbaliferiz S, Iranshahi M. Prooxidant activity of polyphenols, flavonoids, anthocyanins and carotenoids: Updated review of mechanisms and catalyzing metals. Phytother. Res. 30: 1379-1391 (2016)

Erdmann ME, Zeeb B, Salminen H, Gibis M, Lautenschlaeger R, Weiss J. Influence of droplet size on the antioxidant activity of rosemary extract loaded oil-in-water emulsions in mixed systems. Food Funct. 6: 793-804 (2015) https://doi.org/10. 1039/c4fo00878b

Fabre G, Bayacha I, Berka K, Paloncýová M, Starok M, Rossi C, Duroux J-L, Otyepka M, Trouillas P. Synergism of antioxidant action of vitamins $\mathrm{E}, \mathrm{C}$ and quercetin is related to formation of molecular associates in biomembranes. Chem. Commun. 51: 7713-7716 (2015)

Fang X, Wada S. Enhancing the antioxidant effect of $\alpha$-tocopherol with rosemary in inhibiting catalyzed oxidation caused by $\mathrm{Fe}^{2+}$ and hemoprotein. Food Res. Int. 26: 405-411 (1993)

Farnad N, Heidari R, Aslanipour B. Phenolic composition and comparison of antioxidant activity of alcoholic extracts of peppermint (Mentha piperita). J. Food Measure. 8: 113-121 (2014)

Farooq S, Sehgal A. Synergistic antioxidant interactions between green tea and Ocimum gratissimum. Asian Pac. J. Trop. Biomed. 9: 333-338 (2019)

Fotovvat M, Radjabian T, Saboora A. HPLC fingerprint of important phenolic compounds in some Salvia L. species from Iran. Rec. Nat. Prod. 13: 37-49 (2018) https://doi.org/10.25135/ rnp.72.18.02.228

Frankel EN, Huang SW, Aeschbach R, Prior E. Antioxidant activity of a rosemary extract and its constituents, caronosic acid, carnosol, and rosmarinic acid, in bulk oil and oil-in-water emulsion. J. Agr. Food Chem. 44: 131-135 (1996)

Frankel EN, Huang SW, Kanner J, German JB. Interfacial phenomena in the evaluation of antioxidants - bulk oils vs emulsions. J. Agr. Food Chem. 42: 1054 - 1059 (1994)

Frankel EN, Satue-Gracia T, Meyer AS, German JB. Oxidative stability of fish and algae oils containing long-chain polyunsaturated fatty acids in bulk and in oil-in-water emulsions. J. Agr. Food Chem. 50: 2094-2099 (2002)

Freiría-Gándara J, Losada-Barreiro S, Paiva-Martins F, Bravo-Díaz C. Enhancement of the antioxidant efficiency of gallic acid derivatives in intact fish oil-in-water emulsions through optimization of their interfacial concentrations. Food Funct. 9: 4429-4442 (2018)
Fumiaki M, Tomoko S, Michihiro Y, Toshio Y. O/W/O type multiphase emulsion. National Center for Biotechnology Information. PubChem Database; Patent $=$ EP0970741 (2008). Available from: https://pubchem.ncbi.nlm.nih.gov/patent/EP0970741. Accessed Feb. 9, 2019.

Gallego MG, Gordon MH, Segovia FJ, Skowyra M, Almajano MP. Antioxidant properties of three aromatic herbs (rosemary, thyme and lavender) in oil-in-water emulsions. J. Am. Oil Chem. Soc. 90: 1559-1568 (2013)

Gao B, Chena L, Chen T. Effect of electron-donating substituent groups on aromatic ring on photoluminescence properties of complexes of benzoic acid-functionalized polysulfone with Eu(iii) ions. Phys. Chem. Chem. Phys. 17: 25322-25332 (2015)

García-Pérez P, Lozano-Milo E, Gallego PP, Tojo C, Losada-Barreiro S, Bravo-Díaz C. Plant antioxidants in food emulsions. In: Some New Aspects of Colloidal Systems in Foods. Milani JM (ed). IntechOpen, Rijeka (2018). https://doi.org/10.5772/intechopen. 79592

Giacometti J, Bursać Kovačević D, Putnik P, Gabric D, Bilušić T, Kresic G, Stulić V, Barba F, Chemat F, Barbosa-Cánovas G, Režek Jambrak A. Extraction of bioactive compounds and essential oils from Mediterranean herbs by conventional and green innovative techniques: A review. Food Res. Int. 113: 245-262 (2018). https://doi.org/10.1016/j.foodres.2018.06.036.

Guedon DJ, Pasquier BP. Analysis and distribution of flavonoid glycosides and rosmarinic acid in Mentha piperita clones. J. Agr. Food Chem. 42: 679-684 (1994)

Hadjmohammadi M, Karimiyan H, Sharifi V. Hollow fibre-based liquid phase microextraction combined with high-performance liquid chromatography for the analysis of flavonoids in Echinophora platyloba DC and Mentha piperita. Food Chem. 141: 731-735 (2013)

Halliwell B, Gutteridge JMC. Free radicals in biology and medicine. 3rd ed. New York: Oxford University Press. p 297. (2001)

Haslama E, Cai Y. Plant polyphenols (Vegetable tannins): Gallic acid metabolism. Nat. Prod. Rep. 11: 41-66 (1994)

Hazahari N, Hosokawa M, Miyashita K. Comparison of oxidative stability of monogalactosyl diacylglycerol, digalactosyl diacylglycerol, and triacylglycerol containing polyunsaturated fatty acids. Food Nutr. Sci. 9: 221-234 (2018)

Hennere G, Prognon P, Brion F, Nicolis I. Molecular dynamics study of a phospholipid monolayer at a water/triglyceride interface: towards lipid emulsion modelling. Chem. Phys. Lipids 157: 86-93 (2009a)

Hennere G, Prognon P, Brion F, Rosilio V, Nicolis I. Molecular dynamics simulation of a mixed lipid emulsion model: Influence of the triglycerides on interfacial phospholipid organization. J. Mol. Struct. Theochem. 901: 174-185 (2009b)

Horn AF, Nielsen NS, Jensen LS, Horsewell A, Jacobsen C. The choice of homogenisation equipment affects lipid oxidation in emulsions. Food Chem. 134: 803-810 (2012)

Huang S-W, Frankel EN, Schwarz K, Aeschbach R, German JB. Antioxidant activity of carnosic acid and methyl carnosate in bulk oils and oil-in-water emulsions. J. Agr. Food Chem. 44: 2951-2956 (1996)

Ito T, Tsuji Y, Aramaki K, Tonooka N. Two-step emulsification process for water-in-ol-in-water multiple emulsions stabilized by lamellar liquid crystals. J. Oleo Sci. 61: 413-420 (2012)

Jacobsen C, Hartvigsen K, Thomsen MK, Hansen LF, Lund P, Skibsted LH, Hølmer G, Adler-Nissen J, Meyer AS. Lipid oxidation in fish oil enriched mayonnaise: calcium disodium ethylenediaminetetraacetate, but not gallic acid, strongly inhibited oxidative deterioration. J. Agr. Food Chem. 49: 1009-1019 (2001)

Jacobsen C. Oxidative stability and shelf life of food emulsions. pp. 287-312. In: Oxidative Stability and Shelf Life of Foods 
Containing Oils and Fats. Hu M, Jacobsen C (eds). Elsevier Inc., Amsterdam (2016). https://doi.org/10.1016/b978-1-63067-0566.00008-2

Jain DP, Pancholi SS, Patel R. Synergistic antioxidant activity of green tea with some herbs. J. Adv. Pharm. Technol. Res. 2: 177-183 (2011)

Jovanovic SV, Steenken S, Hara Y, Simic MG. Reduction potentials of flavonoid and model phenoxyl radicals. Which ring in flavonoids is responsible for antioxidant activity? J. Chem. Soc. Perkin Trans. 2: 2497-2504 (1996)

Jovanovic SV, Simic MG, Steenken S, Hara Y. Iron complexes of gallocatechins. Antioxidant action or iron regulation? J. Chem. Soc., Perkin Trans. 2: 2365-2370 (1998)

Kabri TH, Meynier A, Bontemps D, Gaillard C, Foucat L, Linder M, Genot C. Formulation of sub-micron emulsions containing docosahexaenoic acid esterified in triacylglycerols or phospholipids. Eur. J. Lipid Sci. Technol. 115: 1294-308 (2013)

Kaliora AC, Kogiannou DAA, Kefalas P, Papassideri IS, Kalogeropoulos N. Phenolic profiles and antioxidant and anticarcinogenic activities of greek herbal infusions; balancing delight and chemoprevention? Food Chem. 142: 233-241 (2014)

Katalinic V. Investigation of the potential synergistic effect of resveratrol with other phenolic compounds: A case of binary phenolic mixtures. J. Food Comp. Anals. 38: 13-18 (2015)

Khan MA, Shahidi F. Oxidative stability of stripped and nonstripped borage and evening primrose oils and their emulsions in water. J. Am. Oil Chem. Soc. 77: 963-968 (2000)

Kim J, Choe E. Effect of the $\mathrm{pH}$ on the lipid oxidation and polyphenols of soybean oil-in-water emulsion with added peppermint (Mentha piperita) extract in the presence and absence of iron. Food Sci. Biotechnol. 27: 1285-1292 (2018)

Kim J, Choe E. Effects of selected herb extracts on iron-catalyzed lipid oxidation in soybean oil-in-water emulsion. Food Sci. Biotechnol. 25: 1017-1022 (2016)

Kim J-H, Choe E-O. Interaction effect of tocopherol homologs with peppermint extract on the iron-catalyzed oxidation of soybean oil-in-water emulsion. Food Sci. Biotechnol. 28: 1679-1685 (2019)

Kim J, Lee H, Choe E. Effects of basil extract and iron addition on the lipid autoxidation of soybean oil-in-water emulsion with high oil content. Korean J. Food Cook. Sci. 33: 113-120 (2017)

Kristinová V, Mozuraityte R, Storrø I, Rustad T. Antioxidant activity of phenolic acids in lipid oxidation catalyzed by different prooxidants. J. Agr. Food Chem. 57: 10377-10385 (2009)

Kurek-Górecka A, Rzepecka-Stojko A, Górecki M, Stojko Sosada JM, Świerczek-Zięba G. Structure and antioxidant activity of polyphenols derived from propolis. Molecules 19: 78-101 (2014). https://doi.org/10.3390/molecules 19010078

Laguerre M, Bily A, Roller M, Birtić S. Mass transport phenomena in lipid oxidation and antioxidation. Annu. Rev. Food Sci. Technol. 8: 391-411 (2017)

Lee H. Choe E. Contribution of minor compounds present in the peppermint (Mentha piperita) to the iron-catalyzed lipid oxidation of soybean oil-in-water emulsion. Food Sci. Biotechnol. 27: 1319-1325 (2018)

Lee Y, Choe E. Interaction of phosphatidylcholine and $\alpha$-tocopherol on the oxidation of sunflower oil and content changes of phosphatidylcholine and tocopherol in the emulsion under singlet oxygen. J. Food Sci. 76: C498-503 (2011)

Lemanska K, van der Woude $H$, Szymusiak H, Boersma M, Gliszczyńska-Świgło A, Rietjens I, Tyrakowska B. The effect of catechol O-methylation on radical scavenging characteristics of quercetin and luteolin-A mechanisticiInsight. Free Rad. Research. 38: 639-647 (2004)

Lisete-Torres P, Losada-Barreiro S, Albuquerque H, Sánchez-Paz V, Paiva-Martins, F, Bravo-Díaz C. Distribution of hydroxytyrosol and hydroxytyrosol acetate in olive oil emulsions and their antioxidant efficiency. J. Agr. Food Chem. 60: 7318-7325 (2012)

Losada-Barreiro S, Bravo Díaz C, Paiva Martins F, Romsted LS. Maxima in antioxidant distributions and efficiencies with increasing hydrophobicity of gallic acid and its alkyl esters. The pseudophase model interpretation of the "cut-off effect". J. Agr. Food Chem. 61: 6533-6543 (2013b)

Losada-Barreiro S, Costa M, Bravo-Díaz C, Paiva-Martins F. Distribution and antioxidant efficiency of resveratrol in stripped corn oil emulsions. Antioxidants 3: 212-228 (2014). doi: https:// doi.org/10.3390/antiox3020212

Losada-Barreiro S, Sánchez Paz V, Bravo-Díaz C. Effects of emulsifier hydrophile-lipophile balance and emulsifier concentration the distributions of gallic acid, propyl gallate, and $\alpha$ tocopherol in corn oil emulsions. J. Colloid Interface Sci. 389: 1-9 (2013a)

Loughrin JH, Kasperbauer MJ. Light reflected from colored mulches affects aroma and phenol content of sweet basil (Ocimum basilicum L.) leaves. J. Agr. Food Chem. 49: 1331-1335 (2001)

Mahoney LR, Weiner SA. Mechanistic study of the dimerization of phenoxyl radicals. J. Am. Chem. Soc. 94: 585-590 (1972)

McClements DJ, Decker EA. Lipid oxidation in oil-in-water emulsions: Impact of molecular environment on chemical reactions in heterogeneous food systems. J. Food Sci. 65: 1270-1282 (2000)

McClements DJ. Lipid-based emulsions and emulsifiers. pp. 63-98. In: Food Lipids: Chemistry, Nutrition, and Biotechnology. 3rd. Akoh CC and Min DB (eds). CRC Press, Inc., Boca Raton, FL. USA (2008)

Medina I, Undeland I, Larsson K, Storro I, Rustad T, Jacobsen C, Kristinova V, Gallardo JM. Activity of caffeic acid in different fish lipid matrices: A review. Food Chem. 131: 730-740 (2012)

Mei L, McClements DJ, Wu J, Decker EA. Iron-catalyzed lipid oxidation in emulsions as affected by surfactant, $\mathrm{pH}$, and $\mathrm{NaCl}$. Food Chem. 61: 307-312 (1998)

Mena P, Cirlini M, Tassotti M, Herrlinger KA, Dall'Asta C, Rio DD. Phytochemical profiling of flavonoids, phenolic acids, terpenoids, and volatile fraction of a rosemary (Rosmarinus officinalis L.) extract. Molecules 21: 1576 (2016). https://doi.org/10.3390/molecules21111576

Mihov R, Nikovska KR, Nenov N, Slavchev A. Evaluation of mayonnaise-like food emulsions with extracts of herbs and spices. Emir. J. Food Agric. 24: 191-199 (2012)

Mirhosseini H, Tan CP, Hamid NSA, Yusof S. Modeling the relationship between the main emulsion components and stability, viscosity, fluid behavior, $\zeta$-potential and electrophoretic mobility of orange beverage emulsion using response surface methodology. J. Agr. Food Chem. 55: 7659-7666 (2007)

Miura YH, Tomita I, Watanabe T, Hirayama T, Fukui S. Active oxygens generation by flavonoids. Biol. Pharm. Bull. 21: 93-96 (1998)

Moreno S, Scheyer T, Romano CS, Vojnov AA. Antioxidant and antimicrobial activities of rosemary extracts linked to their polyphenol composition. Free Radic. Res. 40: 223-231 (2006)

Navarre DA, Shakya R, Hellmann H. Vitamins, phytonutrients, and minerals in potato. pp. 117-166. In: Advances in Potato Chemistry and Technology. $2^{\text {nd }}$. Editor(s): Singh J and Kaur L (eds). Academic Press, Boca Raton (2016). https://doi.org/10. 1016/B978-0-12-800002-1.00006-6

Nikovska K. Study of olive oil-in-water emulsions with protein emulsifiers. Emir. J. Food Agric. 24: 17-24 (2012)

Olszowy M, Dawidowicz AL, Jóźwik-Dolęba M. Are mutual interactions between antioxidants the only factors responsible for antagonistic antioxidant effect of their mixtures? Additive and antagonistic antioxidant effects in mixtures of gallic, ferulic and caffeic acids. Eur. Food Res. Technol. 245: 1473-1485 (2019) 
Pandey MK, Kunchur HS, Ananthnag GS, Mague JT, Balakrishna MS. Catechol and 1,2,4,5-tetrahydroxybenzene functionalized cyclodiphosphazane ligands: synthesis, structural studies, and transition metal complexes. Dalton Trans. 48: 3610-3624 (2019)

Paiva-Martins F, Santos V, Mangericão H, Gordon MH. Effects of copper on the antioxidant activity of olive polyphenols in bulk oil and oil-in-water emulsions. J. Agr. Food Chem. 54: 3738-3743 (2006)

Panya A, Kittipongpittaya K, Laguerre M, Bayrasy C, Lecomte J, Villeneuve P, Mcclements DJ, Decker EA. Interactions between $\alpha$-tocopherol and rosmarinic acid and its alkyl esters in emulsions: Synergistic, additive, or antagonistic effect?. J. Agr. Food Chem. 60: 10320-10330 (2012)

Pan Z, Li H, Zheng S, Zhang B, Deng Z-Y. Implication of the significance of dietary compatibility: based on the antioxidant and anti-inflammatory interactions with different ratios of hydrophilic and lipophilic antioxidants among four daily agricultural crops. J. Agr. Food Chem. 66: $7461-7474$ (2018)

Park YJ, Baek S-A, Choi Y, Kim JK, Park SU. Metabolic profiling of nine Mentha species and prediction of their antioxidant properties using chemometrics. Molecules 24: 258 (2019). https://doi. org/10.3390/molecules 24020258

Pawar N, Gandhi K, Purohit A, Arora S, Singh RRB. Effect of added herb extracts on oxidative stability of ghee(butter oil) during accelerated oxidation condition. J. Food Sci. Technol. 51: 2727-2733 (2014). https://doi.org/10.1007/s13197-012-0781-1

Pereira D, Pinheiro RS, Heldt FS, de Moura C, Bianchin M, Almeida JF, Reis AS, Ribeiro IS, Haminiuk CWI, Carpes ST. Rosemary as natural antioxidant to prevent oxidation in chicken burgers. Food Sci. Technol Camp. 37: 17-23 (2017)

Peter KV, Shylaja MR. Introduction to herbs and spices: definitions, trade and applications. Vol. 1. pp.1-24. In: Handbook of herbs and spices. Peter KV (ed). Woodhead Publishing Ltd., Cambridge (2004)

Peyrat-Maillard MN, Cuvelier ME, Berset C. Antioxidant activity of phenolic compounds in 2,2-azobis (2-amidinopropane) dihydrochloride (AAPH)-induced oxidation: synergistic and antagonistic effects. J. Am. Oil Chem. Soc. 80: 1007-1012 (2013)

Pirker KF, Baratto MC, Basosi R, Goodman BA. Influence of pH on the speciation of copper(II) in reactions with the green tea polyphenols, epigallocatechin gallate and gallic acid. J. Inorg. Biochem. 112: 10-16 (2012)

Ponginebbi L, Nawar W, Chinachoti P. Oxidation of linoleic acid in emulsions: Effect of substrate, emulsifier, and sugar concentration. J. Am. Oil Chem. Soc. 76: 131-138 (1999)

Porter WL, Black ED, Drolet AM. Use of polyamide oxidative fluorescence test on lipid emulsions: Contrast in relative effectiveness of antioxidants in bulk versus dispersed systems. J. Agr. Food Chem. 37: 615 - 624 (1989)

Poyato C, Navarro-Blasco I, Calvo MI, Cavero RY, Astiasaran I, Ansorena D. Oxidative stability of $\mathrm{O} / \mathrm{W}$ and $\mathrm{W} / \mathrm{O} / \mathrm{W}$ emulsions: Effect of lipid composition and antioxidant polarity. Food Res. Int. 51: 132-140 (2013)

Proestos C, Komaitis M. Analysis of naturally occurring phenolic compounds in aromatic plants by RP-HPLC coupled to diode array detector (DAD) and GC-MS after silylation. Foods 2: 90-99 (2013)

Resurreccion AVA, Reynold AE, Jr. Evaluation of natural antioxidants in frankfurters containing chicken and pork. J. Food Sci. 55: 629-631 (1990)

Ríha M, Karlícková J, Filipský T, Jahodár L, Hrdina R, Mladenka P. In vitro copper-chelating properties of flavonoids. RSC Adv. 4: 32628-32638 (2014). doi: https://doi.org/10.1039/C4RA04575K

Serdaroglu M, Öztürk B, Kara A. An overview of food emulsions: Description, classification and recent potential applications.
Turk. J. Agric. Food Sci. Technol. 3: 430-438 (2015). https://doi.org/10.24925/turjaf.v3i6.430-438.336

Shan B, Yizhong Z, Cai Z, Sun M, Corke H. Antioxidant capacity of 26 spice extracts and characterization of their phenolic constituents. J. Agr. Food Chem. 53: 7749-7759 (2005)

Shahidi F, Zhong Y. Revisiting the polar paradox theory: A critical overview J. Agr. Food Chem. 59: 3499-3504 (2011)

Shishido S, Miyano R, Nakashima T, Matsuo H, Iwatsuki M, Nakamura K, Kanno T, Egusa H, Niwano Y. A novel pathway for the photooxidation of catechin in relation to its prooxidative activity. Sci. Rep. 8: 12888 (2018). https://doi.org/10.1038/ s41598-018-31195-x

Siebert KJ, Troukhanova NV, Lynn PY. Nature of polyphenolprotein interactions. J. Agr. Food Chem. 44: 180-185 (1996)

Simić A, Manojlović D, Segan D, Todorović M. Electrochemical behavior and antioxidant and prooxidant activity of natural phenolics. Molecules 12: 2327-2340 (2007). https://doi.org/10. 3390/12102327

Sleeter RT. Effect of processing on quality of soybean oil. J. Am. Oil Chem. Soc. 58: 239-247 (1981)

Solecka, D. Role of phenylpropanoid compounds in plant responses to different stress factors. Acta Physiol. Plant. 19: 257-268 (1997)

Sonam KS, Guleria S. Synergistic antioxidant activity of natural products. Ann. Pharmacol. Pharm. 2(16): 1086 (2017)

Sørensen ADM, Villeneuve P, Jacobsen C. Alkyl caffeates as antioxidants in $\mathrm{O} / \mathrm{W}$ emulsions: Impact of emulsifier type and endogenous tocopherols. Eur. J. Lipid Sci. Technol. Spec. Issue 119: 1600276 (2017). https://doi.org/10.1002/ejlt.201600276

Traynor MP, Burke R, Frías JM, Gaston E, Barry-Ryan C. Formation and stability of an oil in water emulsion containing lecithin, xanthan gum and sunflower oil. Int. Food Res. J. 20: 2173-2181 (2013)

Vallverdú-Queralt A, Regueiro J, Alvarenga JFR. Martinez-Huelamo M, Leal LN, Lamuela-Raventos RM. Characterization of the phenolic and antioxidant profiles of selected culinary herbs and spices: caraway, turmeric, dill, marjoram and nutmeg. Food Sci. Technol, Campinas. 35: 189-195 (2015)

Vallverdú-Queralt A, Regueiro J, Martínez-Huélamo M, Alvarenga JFR, Leal LN, Lamuela-Raventos RM. A comprehensive study on the phenolic profile of widely used culinary herbs and spices: Rosemary, thyme, oregano, cinnamon, cumin and bay. Food Chem. 154: 299-307 (2014)

Wada S, Fang X. The synergistic antioxidant effect of rosemary extract and $\alpha$-tocopherol in sardine oil model system and frozencrushed fish meat. J. Food Process. Preserv. 16: 263-274 (1992)

Walch SG, Tinzoh LN, Zimmermann BF, Stühlinger W, Lachenmeier DW. Antioxidant capacity and polyphenolic composition as quality indicators for aqueous infusions of Salvia officinalis L. (sage tea). Front. Pharmacol. 2: 79 (2011). https://doi.org/10. 3389/fphar.2011.00079

WHO. Copper in Drinking-water. World Health Organization (2004). Available from: https://www.who.int/water_sanitation_health/ dwq/chemicals/copper.pdf. Accessed on March 16, 2020

WHO. Iron in Drinking-water. World Health Organization (2003). Available from: https://www.who.int/water_sanitation_health/ dwq/chemicals/iron.pdf. Accessed on March 16, 2020

Wojdyło A, Oszmiański J, Czemerys R. Antioxidant activity and phenolic compounds in 32 selected herbs. Food Chem. 105: 940-949 (2007)

Wong JW, Hashimoto K. Shibamoto T. Antioxidant activities of rosemary and sage extracts and vitamin $\mathrm{E}$ in a model system. J. Agr. Food Chem. 43: 2707-2712 (1995)

Wong PYY, Kitts DD. Studies on the dual antioxidant and antibacterial properties of parsley (Petroselinum crispum) and cilantro (Coriandrum sativum) extracts. Food Chem. 97: 505-515 (2006) 
$\mathrm{Xu}$ Z. Mechanics of metal-catecholate complexes: The roles of coordination state and metal types. Sci. Rep. 3: 2914 (2013)

Yeomans VC, Linseisen J, Wolfram G. Interactive effects of polyphenols, tocopherol and ascorbic acid on the $\mathrm{Cu}^{2+}$-mediated oxidative modification of human low density lipoproteins. Eur. J. Nutr. 44: 422-428 (2005)

Yordi EG, Pérez EM, Matos MJ, Villares EU. Antioxidant and prooxidant effects of polyphenolic compounds and structure-activity relationship evidence. pp. 23-48. In: Nutrition, Well-Being and Health. Bouayed J and Bohn T (eds). InTech, Croatia (2012)

Yoshida K, Yanaki T, Yamaguchi M, Watanabe H, Kurosawa T, Ito $\mathrm{K}$. O/W/O type multiple emulsion and method of preparing the same. U.S. Patent 5985177A (1999)

Zeraik ML, Petrônio MS, Coelho D, Regasini LO, Silva DHS, da Fonseca LM, Machado SAS, Bolzani VS, Ximenes VF. Improvement of pro-oxidant capacity of protocatechuic acid by esterification. PLoS ONE 9: e110277 (2014). doi: https://doi.org/ 10.1371/journal.pone.0110277.
Zhao H, Dong J, Lu J, Chen J, Li Y, Shan L, Lin Y, Fan W, Gu G. Effects of extraction solvent mixtures on antioxidant activity eEvaluation and their extraction capacity and selectivity for free phenolic compounds in barley (Hordeum vulgare L.). J. Agr. Food Chem. 54: 7277-7286 (2006)

Zheng W, Wang SY. Antioxidant activity and phenolic compounds in selected herbs. J. Agr. Food Chem. 49: 5165-5170 (2001)

Zheng YZ, Chen DF, Deng G, Guo R. The substituent effect on the radical scavenging activity of apigenin. Molecules 23: 1989 (2018) https://doi.org/10.3390/molecules23081989

Zhou L, Elias RJ. Factors influencing the antioxidant and pro-oxidant activity of polyphenols in oil-in-water emulsions. J. Agr. Food Chem. 60: 2906-2915 (2012)

Publisher's Note Springer Nature remains neutral with regard to jurisdictional claims in published maps and institutional affiliations. 